\title{
TrkB and Neurotrophin-4 Are Important for Development and Maintenance of Sympathetic Preganglionic Neurons Innervating the Adrenal Medulla
}

\author{
Andreas Schober, ${ }^{1}$ Nicole Wolf, ${ }^{1}$ Katrin Huber, ${ }^{1}$ Richard Hertel, ${ }^{1}$ Kerstin Krieglstein, ${ }^{1}$ Liliana Minichiello, ${ }^{3}$ \\ Nitza Kahane, ${ }^{2}$ Johan Widenfalk, ${ }^{4}$ Chaya Kalcheim, ${ }^{2}$ Lars Olson, ${ }^{4}$ Rüdiger Klein, ${ }^{3}$ Gary R. Lewin, ${ }^{5}$ and \\ Klaus Unsicker ${ }^{1}$ \\ ${ }^{1}$ Department of Anatomy and Cell Biology III, University of Heidelberg, D-69120 Heidelberg, Germany, ${ }^{2}$ Department of \\ Anatomy and Embryology, Hebrew University-Hadassah Medical School, Jerusalem 91120, Israel, 3European Molecular \\ Biology Laboratory, Developmental Biology Program, D-69012 Heidelberg, Germany, ${ }^{4}$ Department of Neuroscience, \\ Karolinska Institute, S-17177 Stockholm, Sweden, and ${ }^{5}$ Max Delbrück Institute for Molecular Medicine, \\ Berlin-Buch, D-13122, Germany
}

The adrenal medulla receives its major presynaptic input from sympathetic preganglionic neurons that are located in the intermediolateral (IML) column of the thoracic spinal cord. The neurotrophic factor concept would predict that these IML neurons receive trophic support from chromaffin cells in the adrenal medulla. We show here that adrenal chromaffin cells in the adult rat store neurotrophin (NT)-4, but do not synthesize or store detectable levels of BDNF or NT-3, respectively. Preganglionic neurons to the adrenal medulla identified by retrograde tracing with fast blue or Fluoro-Gold (FG) express TrkB mRNA. After unilateral destruction of the adrenal medulla, $24 \%$ of IML neurons, i.e., all neurons that are preganglionic to the adrenal medulla in spinal cord segments T7-T10, disappear. Administration of NT-4 in gelfoams $(6 \mu \mathrm{g})$ implanted into the medullectomized adrenal gland rescued all preganglionic neurons as evidenced by their presence after 4 weeks. NT-3 and cyto- chrome C were not effective. The action of NT-4 is accompanied by massive sprouting of axons in the vicinity of the NT-4 source as monitored by staining for acetylcholinesterase and synaptophysin immunoreactivity, suggesting that NT-4 may enlarge the terminal field of preganglionic nerves and enhance their access to trophic factors. Analysis of TrkB-deficient mice revealed degenerative changes in axon terminals on chromaffin cells. Furthermore, numbers of FG-labeled IML neurons in spinal cord segments T7-T10 of NT-4-deficient adult mice were significantly reduced. These data are consistent with the notion that NT-4 from chromaffin cells operates through TrkB receptors to regulate development and maintenance of the preganglionic innervation of the adrenal medulla.

Key words: adrenal chromaffin cells; neurotrophins; neurotrophin receptors; spinal cord neurons; knock-out mice; NT-4
Chromaffin cells are neuroendocrine cells of neural crest origin. They share a number of features in common with sympathetic neurons, but require signals for their differentiation that are distinct from signals regulating differentiation of sympathetic neurons (Anderson, 1992; Unsicker, 1993). Sympathetic neurons in paravertebral sympathetic ganglia express the neurotrophin receptor TrkA and require nerve growth factor (NGF) for their development, differentiation, and maintenance (Snider, 1994). In turn, sympathetic neurons synthesize brain-derived neurotrophic factor (BDNF) (Causing et al., 1997) as well as other unidentified factors (see Discussion) for their preganglionic neurons that are located in the intermediolateral column (IML) of the spinal cord. In contrast, chromaffin cells, which also express TrkA (Schober et al., 1997), do not depend on NGF for their development and maintenance (Bode et al., 1986; Schober et al., 1997). Instead, chromaffin cells are widely assumed to require glucocorticoid

Received May 13, 1998; revised June 26, 1998; accepted July 8, 1998.

This work was supported by a grant from Deutsche Forschungsgemeinschaft (SFB 317/D4). We thank B. Brühl and M. Barth for their expert technical assistance. We also thank Genentech, Inc. for a generous gift of NT-4.

Correspondence should be addressed to Dr. Klaus Unsicker, Neuroanatomy, The University of Heidelberg, Im Neuenheimer Feld 307, D-69120 Heidelberg, Germany.

Copyright (ㄷ) 1998 Society for Neuroscience $\quad 0270-6474 / 98 / 187272-13 \$ 05.00 / 0$ hormones for both early and late steps of their development (cf. Cole et al., 1995). Factors made by chromaffin cells that are of physiological importance for the maintenance of their preganglionic neurons have not been identified. Whether chromaffin cells, like sympathetic neurons, synthesize BDNF is not known.

IML neurons that innervate rat adrenal chromaffin cells are concentrated in spinal cord segments T7-T10 (Schramm et al., 1975), where they account for $\sim 25 \%$ of the total population of IML neurons present in these segments (Blottner and Baumgarten, 1992a). In the adult rat, these neurons shrink and disappear after destruction of their target organ, the adrenal medulla (Blottner et al., 1989a,b; Blottner and Unsicker, 1990). Several growth factors that are synthesized and released by chromaffin cells have previously been shown to have a capacity to protect, directly or indirectly, target-deprived IML neurons from death. These include fibroblast growth factor-2 (FGF-2) (Blottner et al., 1989b, Blottner and Unsicker, 1990), ciliary neurotrophic factor (CNTF) (Blottner et al., 1989a), and transforming growth factor- $\beta 2$ (TGF$\beta 2$ ) (Blottner et al., 1996). A physiological role for these factors, however, has not been shown. Although the adult rat adrenal gland is known to synthesize the neurotrophins BDNF, NT-3, and NT-4 (Timmusk et al., 1993; Suter-Crazzolara et al., 1996), neurotrophin synthesis and storage by chromaffin cells has not been documented. Furthermore, a role for putative chromaffin 
cell-derived neurotrophins in regulating IML neuron differentiation and maintenance has not been demonstrated.

The present study demonstrates a key role for NT-4 by showing that the protein is present in chromaffin cells, and the cognate receptor for NT-4, TrkB, is expressed by preganglionic neurons projecting to the adrenal medulla. Preganglionic neurons in spinal cord segments T7-T10 that project to the adrenal medulla are lost after adrenomedullectomy, but can be specifically protected by supplementation of NT-4 to the lesioned adrenal gland. The mechanism underlying the protective actions of NT-4 appears to involve axonal sprouting of lesioned preganglionic neurons. Analyses of TrkB- and NT-4-deficient mice corroborate the notion that NT-4 and TrkB are important in the regulation of development of preganglionic axons to the adrenal medulla and in maintaining an appropriate number of preganglionic neurons innervating the adrenal medulla.

\section{MATERIALS AND METHODS}

Animals. Eighty-five Hanover-Wistar male rats $(250 \mathrm{gm})$ and 12 female Sprague Dawley rats (200 gm; for retrograde transport studies of radiolabeled NT-4) were used. They were kept under standard laboratory conditions with food and water ad libitum and a $12 \mathrm{hr}$ light/dark cycle. In addition, three TrkB $(-/-)$ mice [postnatal day (P) 12] and three corresponding wild-type littermates [for details, see Schober et al. (1997)] as well as seven NT-4 (-/-) mice (adult) and six wild-type mice [for details, see Liu et al. (1995)] were used.

Adrenomedullectomy. Rats were deeply anesthetized by an intraperitoneal injection of $5 \%$ chloral hydrate $(1 \mathrm{ml} / 100 \mathrm{gm}$ body weight). The left adrenal gland was exposed retroperitoneally and medullectomized by electrocauterization using a fine needle electrode (diameter $0.5 \mathrm{~mm}$ ) that was connected to a radiotome (Martin ME 80). The free tip of the isolated electrode was inserted carefully through the cortex into the adrenal medulla. The coagulation was performed by a brief pulse. To test the completeness of the chromaffin tissue destruction, histological control examinations were performed. Thereafter a small piece $\left(1 \mathrm{~mm}^{3}\right)$ of gelfoam (Spongostan, Ferrosan, Soeburg, Denmark) soaked with neurotrophin-3 [NT-3, $2 \mu \mathrm{g} / \mathrm{gelfoam}$ (kindly provided by Genentech, Inc., San Francisco)], neurotrophin-4 [NT-4, 2 or $6 \mu \mathrm{g} / \mathrm{gelfoam}$ (kindly provided by Genentech)], or cytochrome C (Cyt C) $(2$ or $6 \mu \mathrm{g} / \mathrm{gelfoam}$, Serva Feinbiochemica, Heidelberg, Germany) was implanted into the wound cavity and covered by a small drop of tissue glue (Roth $\mathrm{GmbH}$ ).

Fluoro-Gold labeling and tissue preparation. It has been shown previously that intraperitoneal (i.p.) injection of the fluorescent tracer FluoroGold (FG) labels the entire population of viable sympathetic preganglionic neurons in the adult rat spinal cord (Anderson and Edwards, 1994). Twenty-six days after unilateral adrenomedullectomy, $400 \mu \mathrm{l}$ of FG $(0.2 \%$, Fluorochrome Inc.) was injected intraperitoneally, and $48 \mathrm{hr}$ later animals were reanesthetized and transcardially perfused with freshly prepared $4 \%$ paraformaldehyde (PFA). Thereafter the upper thoracic spinal cord was exposed, and spinal cord segments T7-T10 and the operated side were marked. Adrenal glands were removed for monitoring completeness of the medullectomy. After $12 \mathrm{hr}$ of post-fixation $(4 \%$ PFA), longitudinal serial sections of the spinal cord were performed on a vibrating blade microtome (Leica, VT $1000 \mathrm{E}$ ), collected free floating, and mounted on gelatin-coated slides.

Retrograde labeling using fast blue or Fluoro-Gold. To determine the total number of sympathetic preganglionic neurons that innervate adrenal chromaffin cells, the retrograde tracers fast blue (FB) or FG (see above) were injected into the adrenal medulla ( $5 \mu \mathrm{l}$ of $2 \%$ aqueous solution; Sigma, St. Louis, MO). Alternatively, intraperitoneal injections of FG (as described above) were combined with FB-retrograde tracing from the adrenal medulla. Three days after injection, animals were perfused, and spinal cord segments T7-T10 were removed and postfixed. Vibratome sectioning was performed as described before.

Quantitative analysis. Numbers of FB- and FG-labeled preganglionic neurons were determined by cell counts of a complete series of horizontal sections through the IML column of the upper thoracic spinal cord (T7-T10). In all animal groups (NT-3, NT-4, and Cyt C), counts were performed on the left (operated) and right (control) sides. Shamoperated and untreated animals were used to determine the left/right ratio of total numbers of FG-labeled IML neurons. Neuron counts on the right side (control side) were set as $100 \%$. Sections were examined by a Zeiss Axiophot fluorescence microscope using a UV filter set (Zeiss, excitation filter: $390-420 \mathrm{~nm}$; barrier filter: $425-450 \mathrm{~nm}$ ). Only brightly fluorescent IML neurons containing a clearly visible nucleus were counted. Total numbers were corrected for possible double counts of split nuclei according to Abercrombie's formula (Konigsmark, 1970). Results are given as mean values in percent SE (SEM) and tested for statistical significance of side differences by Student's $t$ test.

Immunocytochemistry. Perfused adrenal glands were cryoprotected overnight $(30 \%$ sucrose $)$ and cut on a cryostat $(10 \mu \mathrm{m})$. Sections were then mounted on gelatin-coated slides, dried at room temperature for 30 min, and placed in $0.1 \mathrm{M}$ phosphate buffer (PB), pH 7.4. Spinal cord segments (T7-T10) were cut longitudinally $(30 \mu \mathrm{m})$ on a vibrating slide microtome (VT 1000 E, Leica). Nonspecific binding sites were blocked by preincubation with 5\% normal goat serum (polyclonal antibody) or normal horse serum (monoclonal antibody) containing $0.1 \%$ Triton $\mathrm{X}-100$ diluted in PB for $1 \mathrm{hr}$ at room temperature. Sections were immunostained as follows: (1) incubation with NT-4 polyclonal antibody or BDNF polyclonal antibody (NT-4, catalog \#sc-545; BDNF, catalog \#sc-546; Santa Cruz Biotechnology, Santa Cruz, CA), diluted 1:200 in $\mathrm{PB}$, for $24 \mathrm{hr}$ at room temperature; (2) incubation with biotinylated anti-rabbit IgG (diluted 1:200 in PB, Vector Laboratories, Burlingame, $\mathrm{CA}$ ); and (3) incubation with Cy3-conjugated streptavidin (indocarbocyanine, Jackson ImmunoResearch, West Grove, PA) (diluted 1:1000). Cryosections of medullectomized adrenal glands [for details, see acetylcholinesterase (AChE) histochemistry] were processed for synaptophysin immunocytochemistry (SVP-38, Sigma). Briefly, incubation times and dilutions were as follows: (1) incubation with monoclonal antisynaptophysin antibody, diluted 1:200 in $\mathrm{PB}$, for $24 \mathrm{hr}$ at room temperature; (2) incubation with biotinylated anti-mouse IgG (diluted 1:200 in $\mathrm{PB}$, Vector) for $2 \mathrm{hr}$ at room temperature; and (3) incubation with Cy3-conjugated streptavidin (Jackson, diluted 1:1000) for $2 \mathrm{hr}$ at room temperature. Controls were performed by (1) preabsorbing the antibody to a 20 -fold molar excess of the antigen, or (2) using the corresponding normal serum, or (3) omitting the respective antiserum. Finally, all section were rinsed three times in PB, dried, and embedded in Kaiser's glycerol gelatin.

In situ hybridization of TrkB, TrkC, BDNF, and NT-3 mRNAs. In situ hybridization was performed as described earlier (Kahane and Kalcheim, 1994). Wistar rats of different developmental ages [embryonic day (E) 16, E21, P5, adult] were anesthetized and perfused with 4\% PFA. Adrenal glands and segments of the thoracic spinal cord were dissected, post-fixed $(12 \mathrm{hr}$ ), and processed for paraffin embedding. Deparaffinized sections (7 $\mu \mathrm{m})$ were rehydrated and washed in $0.83 \% \mathrm{NaCl}$ and PBS. Sections were then post-fixed for $10 \mathrm{~min}$ in $4 \%$ PFA, washed two times in PBS, and incubated for $30 \mathrm{~min}$ with proteinase $\mathrm{K}(20 \mu \mathrm{g} / \mathrm{ml}$ in $50 \mathrm{mM}$ Tris $/ 0.5 \mathrm{M}$ EDTA) followed by washes in PBS $/ 0.2 \%$ glycine and PBS. Sections were again post-fixed for $10 \mathrm{~min}$ in $4 \%$ PFA, rinsed in PBS and distilled water, and thereafter incubated for $10 \mathrm{~min}$ in $0.0013 \%$ triethanolamine/ $0.0031 \%$ acetanhydride in $0.05 \mathrm{~N} \mathrm{HCl}$. Finally, slides were washed in PBS and $0.83 \% \mathrm{NaCl}$, dehydrated, and air-dried.

Hybridization was performed in $50 \%$ Formamid, $0.3 \mathrm{M} \mathrm{NaCl}, 20 \mathrm{~mm}$ Tris, pH 7.5, 5 mm EDTA, $10 \%$ Dextransulfate, $1 \times$ Denhardt's solution, $0.5 \mathrm{mg} / \mathrm{ml}$ total yeast tRNA, and $10 \mathrm{~mm}$ dithiothreitol (DTT) using ${ }^{35} \mathrm{~S}$-UTP-labeled cRNA probes (sense or antisense) of murine TrkB (HindII-fragment, $482 \mathrm{bp}$ ) and TrkC (NcoI-fragment, $433 \mathrm{bp}$ ) or BDNF (XbaI/PstI-fragment) and NT-3 (HindIII/SspI-fragment and SspI/SalIfragment, 420 and $218 \mathrm{bp}$, respectively). The NT-3 and BDNF probes were kindly provided by A. Lachmund (Anatomy and Cell Biology III, Heidelberg).

Sections were hybridized overnight at $60^{\circ} \mathrm{C}$ in a humidified chamber. The next day, slides were washed for $1 \mathrm{hr}$ at $55^{\circ} \mathrm{C}$ in $2 \times \mathrm{SSC}, 50 \%$ Formamid, and $10 \mathrm{~mm} \mathrm{DTT}$ and then for $1 \mathrm{hr}$ at $55^{\circ} \mathrm{C}$ in $2 \times \mathrm{SSC}, 50 \%$ Formamid, and $10 \mathrm{~mm}$ DTT. Subsequently slides were rinsed three times for $10 \mathrm{~min}$ at $37^{\circ} \mathrm{C}$ in NTE-buffer $(0.5 \mathrm{M} \mathrm{NaCl}, 10 \mathrm{~mm}$ Tris, $5 \mathrm{~mm}$ EDTA) followed by an incubation for $30 \mathrm{~min}$ at $37^{\circ} \mathrm{C}$ with $20 \mu \mathrm{g} / \mathrm{ml}$ RNase A in NTE-buffer. After a 15 min processing in NTE-buffer, slides were washed for $1 \mathrm{hr}$ at $55^{\circ} \mathrm{C}$ in $2 \times \mathrm{SSC}, 50 \%$ Formamid, and $10 \mathrm{~mm} \mathrm{DTT}$ and then for $15 \mathrm{~min}$ at room temperature in $0.2 \times$ SSC. After dehydration, sections were air-dried, coated with Kodak NTB-2 emulsion (diluted 1:1 in water), and exposed for $4-8$ weeks at $4^{\circ} \mathrm{C}$. After developing, sections were counterstained with hematoxylin and eosin.

Retrograde axonal transport of NT-4. Left adrenal glands of 12 anesthetized adult female Sprague Dawley rats were exposed for microinjection using a $10 \mu$ l Hamilton syringe. One group $(n=8)$ received 


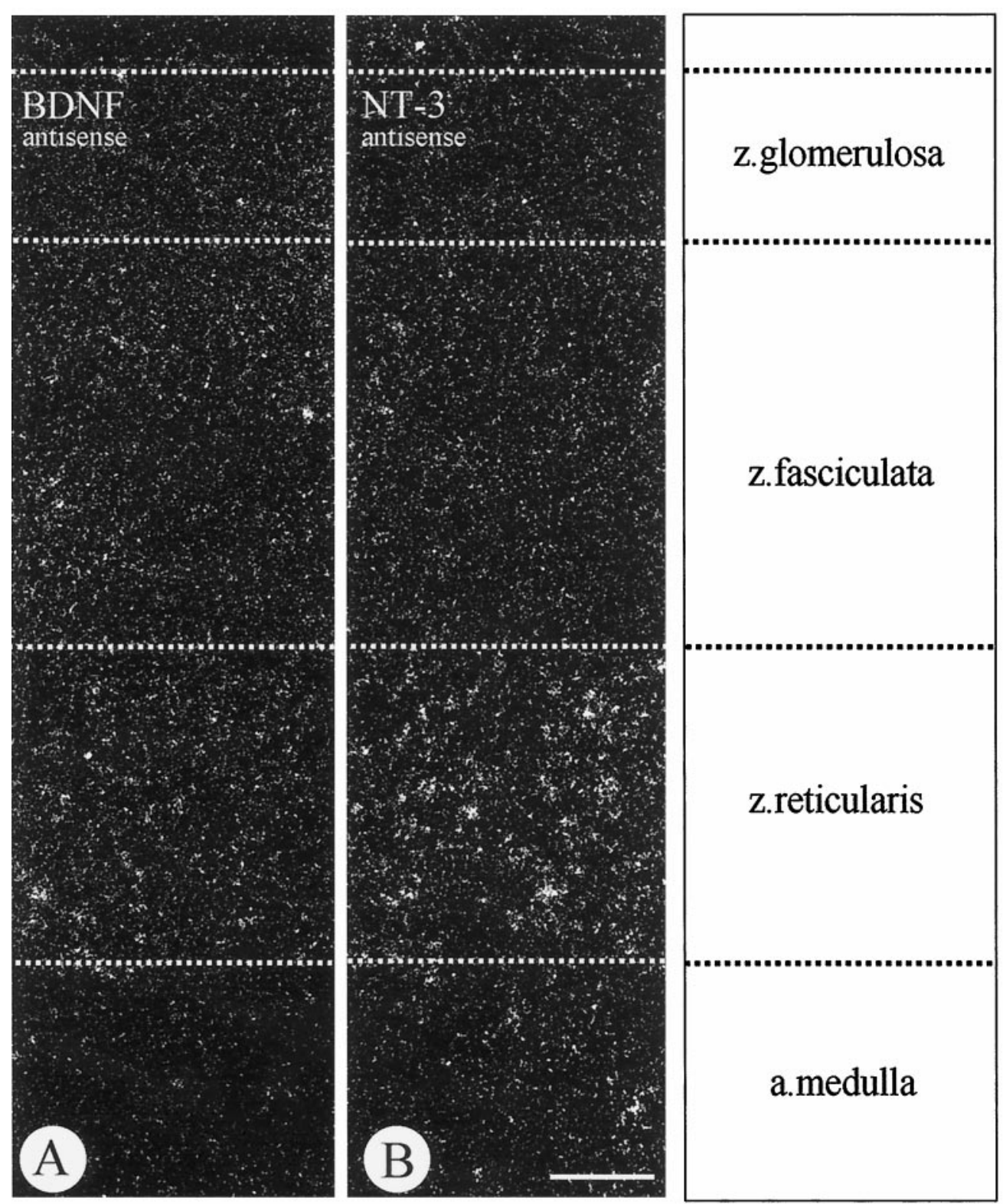

Figure 1. In situ hybridizations of $\operatorname{BDNF}(A)$ and NT-3 $(B)$ mRNAs using antisense probes in the adult rat adrenal gland show specific labeling for both mRNAs in the zona reticularis of the adrenal cortex, but not in the adrenal medulla. NT-3 mRNA is apparently more strongly expressed than BDNF mRNA. Scale bar, $100 \mu \mathrm{m}$.

intramedullary injections of ${ }^{125} \mathrm{I}$ NT-4 (human recombinant; $100 \mu \mathrm{Ci}$ / $\mu \mathrm{g})$ in $2 \mu \mathrm{l} / \mathrm{adrenal}(50 \mathrm{ng} / \mu \mathrm{l}$; injection rate $1 \mu \mathrm{l} / \mathrm{min})$; iodination was performed by Amersham Buchler (Braunschweig, Germany). A control group $(n=4)$ received the same volume $(2 \mu \mathrm{l})$ consisting of $\left({ }^{125} \mathrm{I}\right)$-NT-4 and a 20 -fold excess of cold NT-4. After $18 \mathrm{hr}(n=4)$ or $24 \mathrm{hr}(n=8)$, respectively, animals were perfused, spinal cord segments T7-T10 frozen on dry ice, and horizontal serial cryostat sections $(14 \mu \mathrm{m})$ were collected on coated slides, processed for emulsion autoradiography (cf. Grothe and Unsicker, 1992), and counterstained with cresyl violet. In an additional series of experiments, putative retrograde transport of NT-4 was investigated by implanting a piece of gelfoam soaked with $10 \mu \mathrm{g}$ of NT-4 into medullectomized adrenal glands $(n=3)$. Spinal cord segments T7-T10 were removed after $36 \mathrm{hr}$ and processed for NT-4 immunocytochemistry (see above).

\section{Temporal pattern of reinnervation}

Medullectomized adrenal glands treated with gelfoams containing NT-4 $(n=8)$ or Cyt C $(n=8)$ were analyzed with regard to the time course of reinnervation and axon sprouting $4,8,12$, and $28 \mathrm{~d}$ after surgery by synaptophysin immunocytochemistry (see above) and AChE histochemistry. AChE staining was performed according to a modification of the direct coloring thiocholine method of Karnovsky and Roots (1964) for histochemical detection of AChE activity (Andrä and Lojda, 1986). Animals were perfused by $4 \%$ PFA, and adrenal glands were removed, cryoprotected ( $30 \%$ sucrose), frozen on dry ice, and cut into $10-\mu \mathrm{m}$-thick sections. Sections were mounted on slides and stained for $1 \mathrm{hr}$ at $37^{\circ} \mathrm{C}$ in the following solution $(60 \mathrm{ml}): 30.0 \mathrm{mg}$ of acetylthiocholine iodide (Serva), $44.4 \mathrm{ml}$ of $0.1 \mathrm{~m}$ Tris-maleate buffer, $\mathrm{pH} 5.0$ (containing $0.1 \%$ Triton X-100), $6.0 \mathrm{ml}$ of $0.4 \mathrm{M}$ sodium citrate, $6.0 \mathrm{ml}$ of $0.12 \mathrm{M}$ copper sulfate, $3.0 \mathrm{ml}$ of $0.16 \mathrm{M}$ potassium ferricyanide, and $0.6 \mathrm{ml}$ of $10^{-3} \mathrm{M}$ iso-OMPA (Sigma).

Electron microscopy. Adrenal glands from three TrkB $-/-$ mice and three wild-type littermates (P12) were fixed by transcardial perfusion with $4 \%$ PFA, removed, post-fixed for $48 \mathrm{hr}$ in $2 \%$ glutaraldehyde in PB, and embedded in Epon according to standard protocols.

Analysis of EM data. EM sections were analyzed and photodocumented using a Zeiss electron microscope (EM10A). One hundred synapses located on chromaffin cells of both mutant and wild-type 


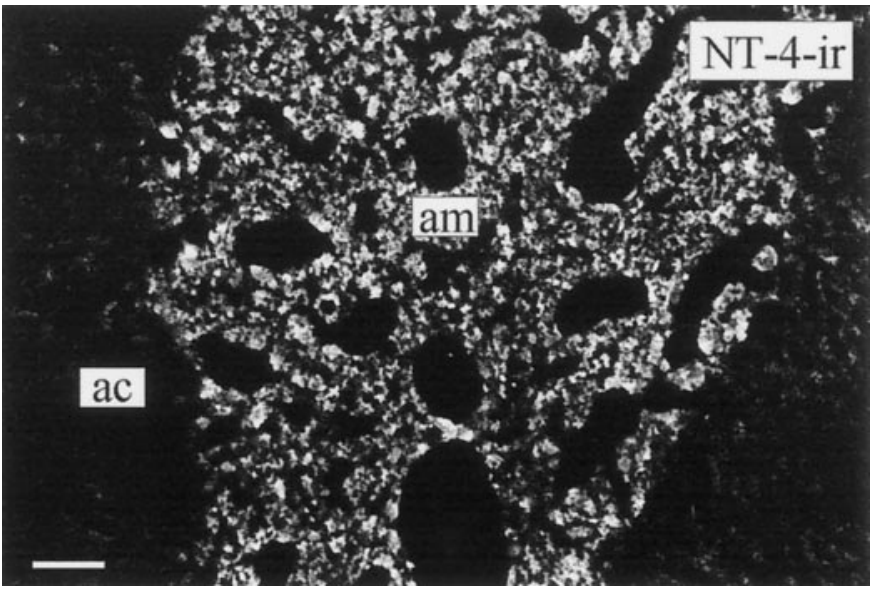

Figure 2. NT-4-ir in chromaffin cells of the adult rat adrenal medulla $(a m)$. The adrenal cortex $(a c)$ is devoid of detectable levels of NT-4-ir. Scale bar, $100 \mu \mathrm{m}$.

adrenal glands were examined. In addition, the length of the synaptic contact zones on chromaffin cells was determined on photographs at $17,630 \times$ magnification using a map measure.

\section{Determination of spinal cord IML neuron numbers in} NT-4-deficient mice

In four NT-4 $(-/-)$ adult mice and three wild-type $(+/+)$ littermates, $150 \mu \mathrm{l}$ of FG ( $0.2 \%$, Fluorochrome Inc.) was injected intraperitoneally, and $48 \mathrm{hr}$ later animals were anesthetized and transcardially perfused with $4 \%$ PFA. Thereafter the upper thoracic spinal cord was exposed, and spinal cord segments T7-T10 were removed. After $12 \mathrm{hr}$ of postfixation (4\% PFA), longitudinal serial sections were performed on a vibrating blade microtome (Leica, VT 1000 E) and collected on gelatincoated slides. FG-labeled IML neurons were counted unilaterally and tested for statistical significance as described before. In addition, in three animals of each genotype $(-/-,+/+)$, the numbers of Nissl-stained IML neurons were determined and compared with the data obtained by FG labeling.

Photomicrographs. Photomicrographs shown in Figures 1-6, 8, and 10 were digitally processed for photoprints regarding brightness, contrast, lettering, and landmarking.

\section{RESULTS}

\section{Expression of BDNF, NT-3, and NT-4 in the adult rat adrenal gland}

To localize the cellular sites of neurotrophin synthesis and storage in the adult rat adrenal gland, in situ hybridization and immunocytochemistry were performed. Figure 1 shows that BDNF and NT-3 are expressed in cells of the innermost cortical layer, the zona reticularis. In addition, BDNF mRNA can be localized in some of the very rare large ganglion cells populating the adrenal medulla (data not shown). Chromaffin cells do not synthesize detectable levels of BDNF or NT-3 mRNAs (Fig. 1). Localization of NT-3 synthesis in the zona reticularis is consistent with the previous localization of NT-3 immunoreactivity in this region (Zhou and Rush, 1993). However, immunostaining did not reveal detectable levels of BDNF protein in the zona reticularis. As shown in Figure 2, all chromaffin cells display immunoreactivity for NT-4. Thus, the above data in conjunction with previous evidence from RNase protection assays and RTPCR (Timmusk et al., 1993; Suter-Crazzolara et al., 1996) and the present immunolocalization suggest chromaffin cells in the adrenal medulla as a major source of NT-4 in the adrenal gland.

\section{Preganglionic neurons to the adrenal medulla express TrkB mRNA}

Because we were not able to detect TrkB mRNA, the cognate receptor for NT-4, in the adrenal medulla by in situ hybridization (data not shown), we investigated whether IML neurons in the
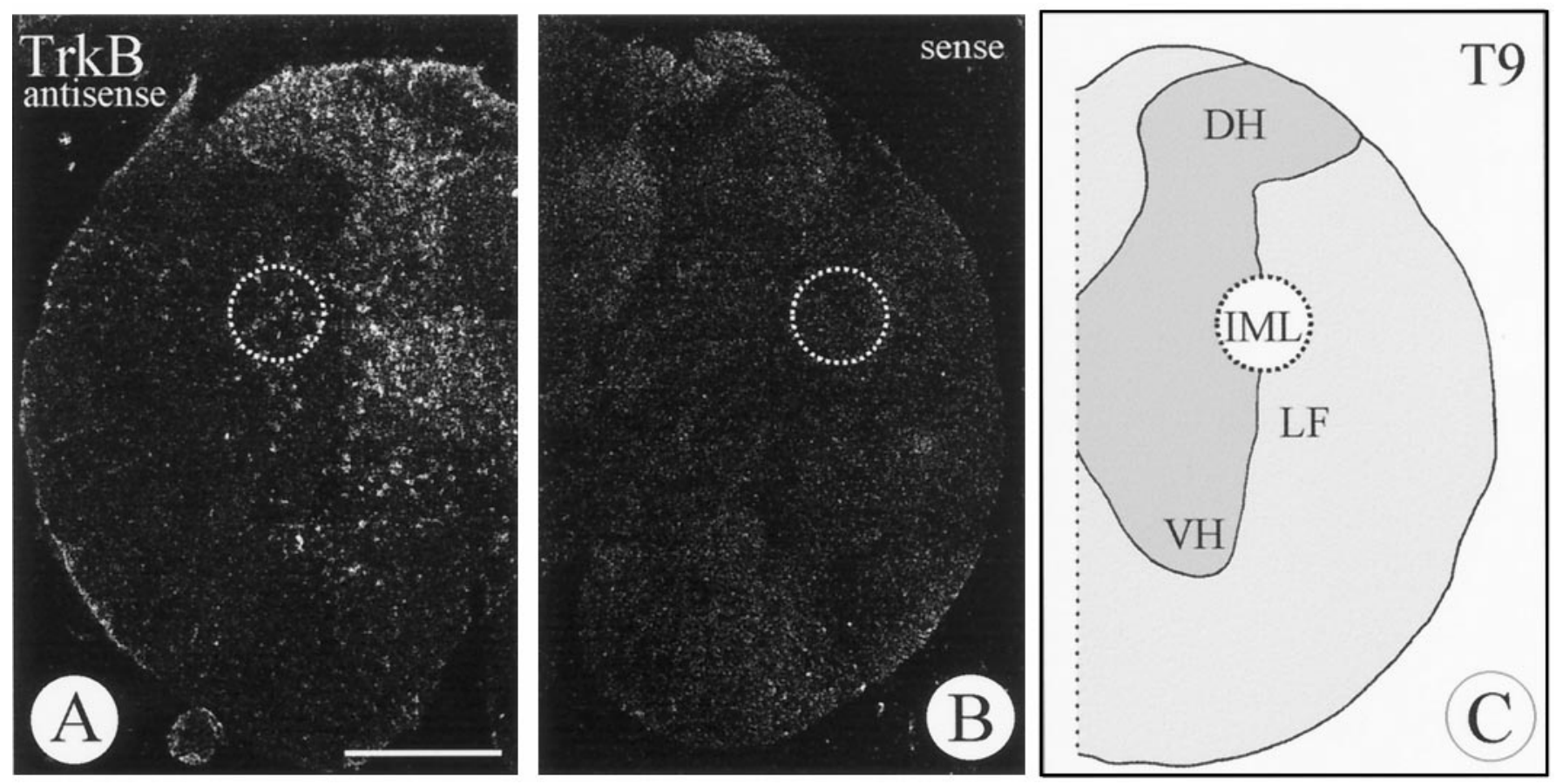

Figure 3. In situ hybridization of TrkB mRNA in the adult rat spinal cord (T9) using antisense $(A)$ and sense $(B)$ probes. Cells in the ventral $(V H)$ and dorsal horns $(D H)$ as well as in the $I M L$ are labeled. $L F$, Lateral funiculus. Scale bar, $1 \mathrm{~mm}$. 

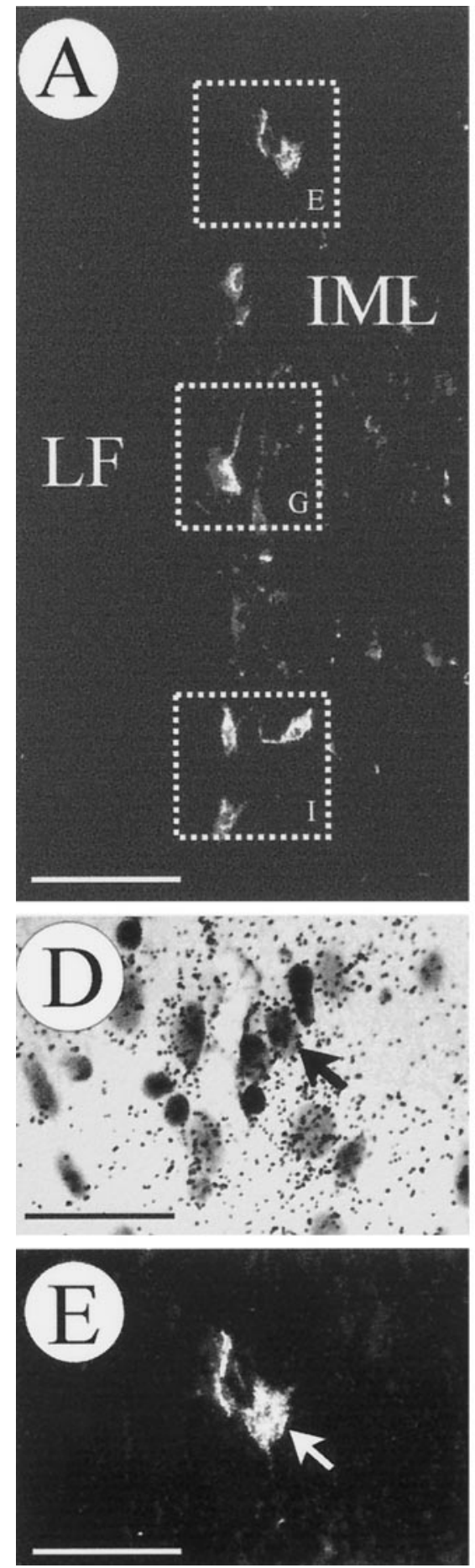
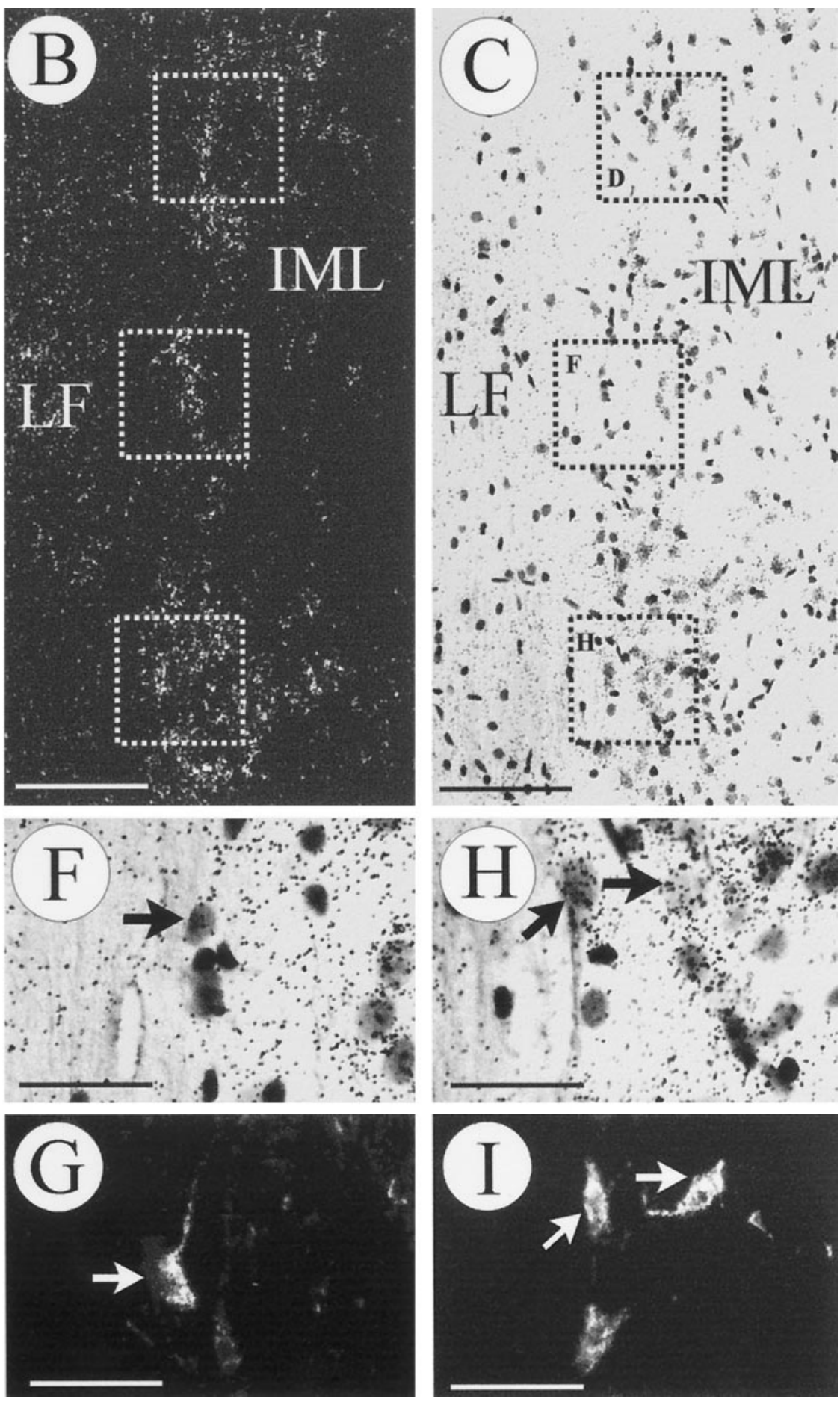

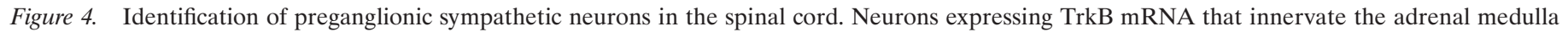

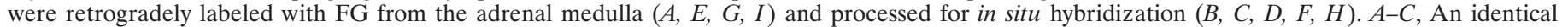

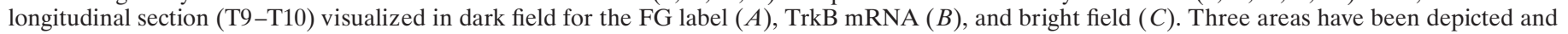

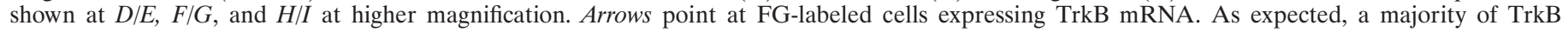

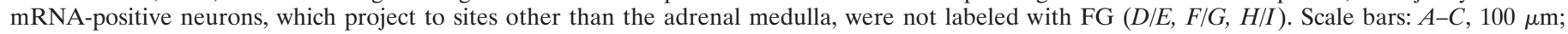
$D-I, 50 \mu \mathrm{m}$.

spinal cord innervating the adrenal medulla were a putative target of chromaffin cell-derived NT-4 by expressing TrkB. As shown in Figures $3 A$ and $4 A-C$, cells in the region of the IML were specifically labeled using an antisense probe to TrkB mRNA. To precisely localize the signal for TrkB mRNA to IML neurons projecting to the adrenal medulla, the following strategy was used. We retrogradely labeled those IML neurons that project to the adrenal medulla using FG (Fig. $4 A, E, G, I$ ) and subsequently processed spinal cord sections between levels $\mathrm{T} 7$ and $\mathrm{T} 10$, which contain the majority of preganglionic neurons for the adrenal medulla (Schramm et al., 1975), for TrkB in situ hybridization (Fig. $4 B, C, D, F, H$ ). As shown in Figure $4 D / E, F / G, H / I$, clusters of 

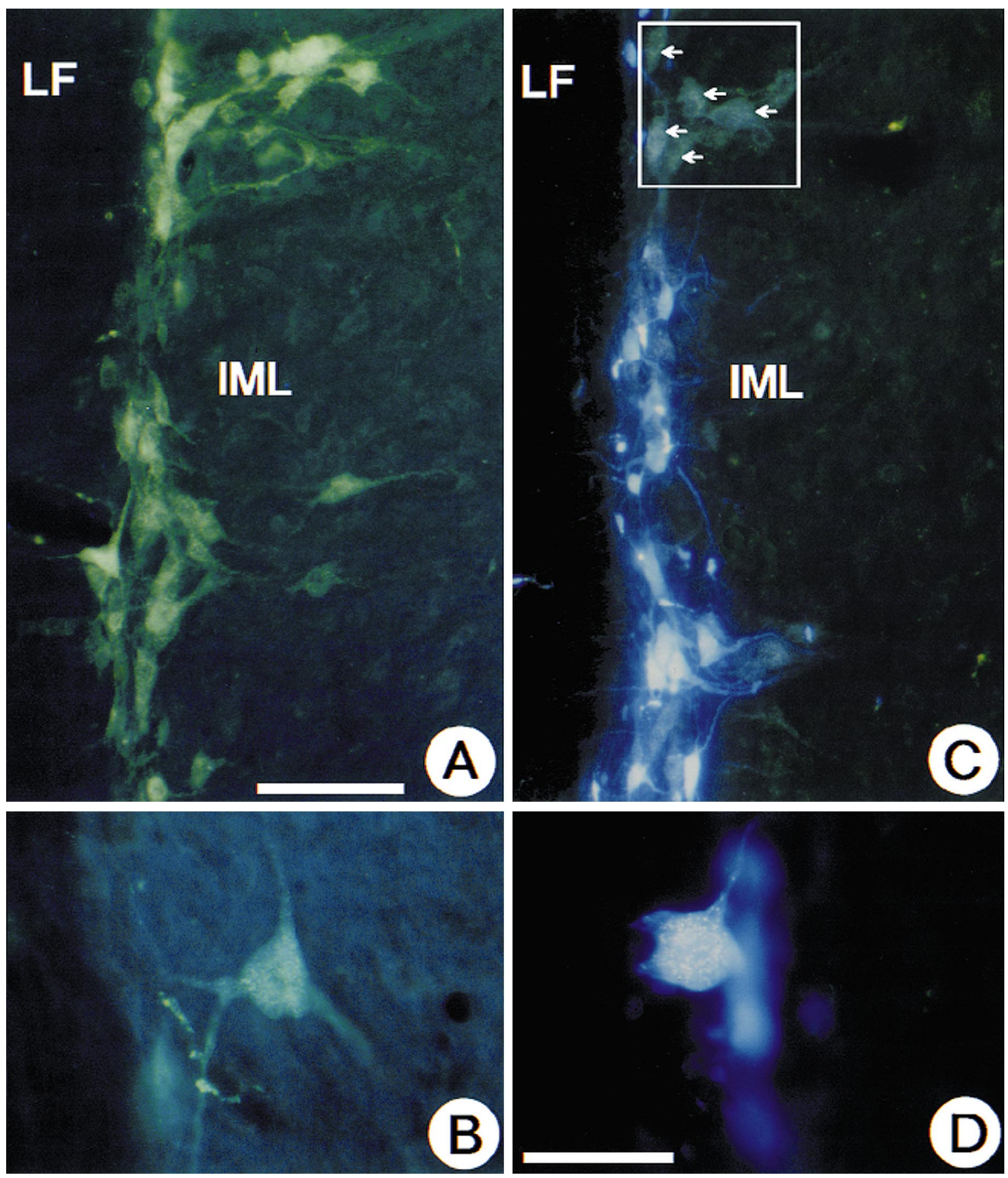

Figure 5. Longitudinal spinal cord section at T9-T10. Demonstration that at this spinal cord level IML neurons that have been retrogradely labeled from the adrenal medulla with FB represent a subpopulation of the total number of IML neurons labeled by intraperitoneally injected FG. $A$ shows the total population of FG-labeled IML neurons after intraperitoneal administration. Note the gold particles in $B$. In $C$ and $D$, neurons containing both FG and FB display an intense blue fluorescence, whereas neurons without FB appear green (white arrows). $D$ shows that gold particles can be clearly seen in FB-labeled neurons at higher magnification. $L F$, Lateral funiculus. Scale bars: $A, C, 100 \mu \mathrm{m} ; B, D, 50 \mu \mathrm{m}$.

silver grains were concentrated over the IML column and could be precisely located over most of the retrogradely labeled IML neurons. As expected, there were also neurons in the IML region positive for TrkB mRNA that were not retrogradely labeled, because they project to targets other than the adrenal medulla
(Fig. 4D/E, $F / G, H / I$ ). A small number of cells expressing TrkC were also observed in the spinal cord within the region of the IML (data not shown). Their identity in terms of being preganglionic to the adrenal medulla was not further investigated, because NT-3 mRNA had not been detected in chromaffin cells. 


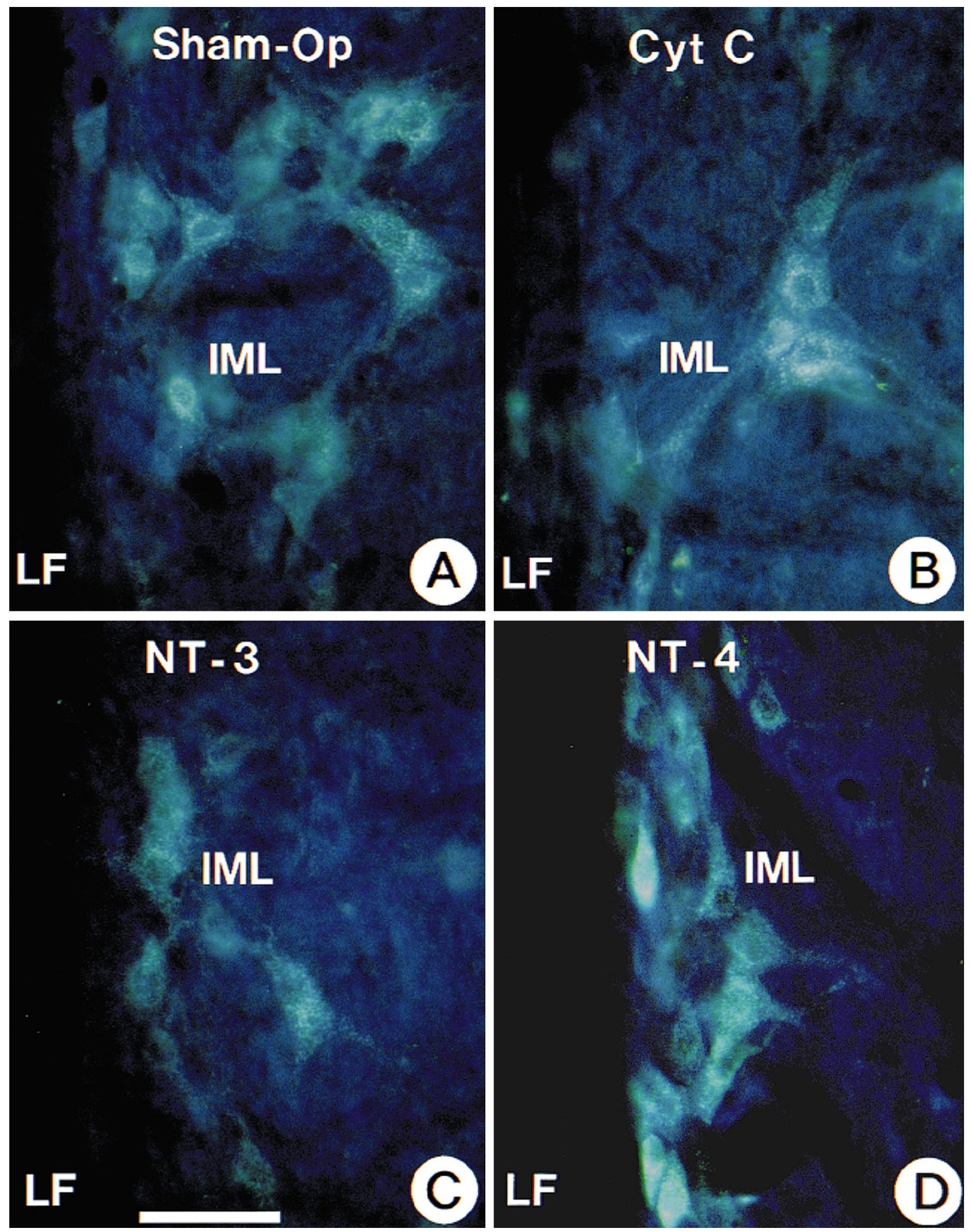

Figure 6. Demonstration of the protective role of NT-4 applied to the medullectomized rat adrenal gland for target-deprived IML neurons. Cytochrome C and NT-3 failed to maintain IML neurons. Neurons were labeled with FG. Scale bar (shown in $C$ ) for $A-D: 100 \mu \mathrm{m}$. 


\section{Effects of neurotrophins on target- deprived IML-neurons}

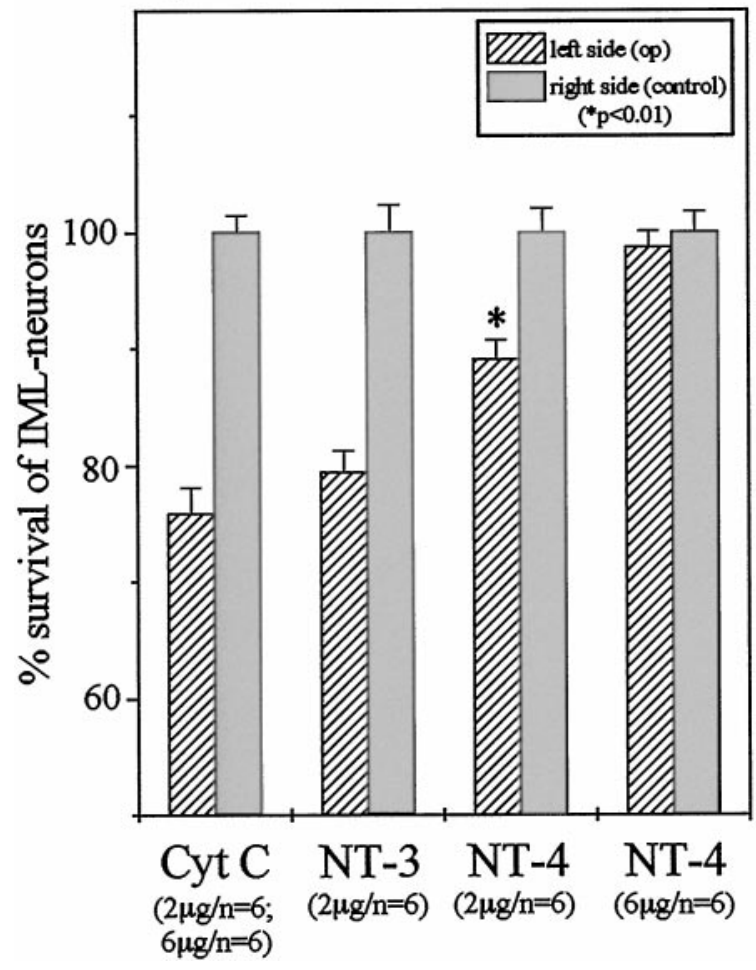

Figure 7. Quantitative determination of IML neuron losses after unilateral adrenomedullectomy and of the rescuing effect of NT-4 applied in gelfoam at 2 and $6 \mu \mathrm{g}$. A dose as low as $2 \mu \mathrm{g}$ of NT-4 still rescued a significant $\left({ }^{*} p<0.01\right)$ number of IML neurons as compared with cytochrome C or NT-3 treatments, respectively.

\section{NT-4, but not NT-3, rescues preganglionic neurons after unilateral adrenomedullectomy}

We have previously documented that unilateral adrenomedullectomy in adult rats causes the loss of all IML neurons in segments T7-T10 that project to the adrenal medulla (Blottner et al., 1989a,b, 1996; Blottner and Unsicker, 1990; Blottner and Baumgarten, 1992a,b). Having now shown that chromaffin cells contain NT-4 and that their preganglionic neurons express TrkB, we investigated whether NT-4 was able to protect these neurons from death induced by target deprivation. Animals were unilaterally adrenomedullectomized by electrocauterization and received a gelfoam implant into the adrenal cavity. Gelfoams were soaked with 6 or $2 \mu \mathrm{g}$, respectively, of either NT-4 or the nontrophic control protein cytochrome $\mathrm{C}$. After $26 \mathrm{~d}$, animals were intraperitoneally injected with $\mathrm{FG}$ for labeling all viable IML neurons (Fig. 5A,B) and killed $48 \mathrm{hr}$ later. In accompanying experiments we had established that IML neurons labeled by intraperitoneal injection of FG (Fig. 5A,B) included the subset of IML neurons that could be retrogradely labeled by $\mathrm{FB}$ (Fig. $5 C, D$ ) from the adrenal medulla. Counts of FG-labeled IML neurons revealed a $24 \%$ (Figs. 6, 7) loss between segments T7 and T10 on the operated as compared with the nonoperated side in animals that had received a gelfoam implant with cytochrome C. As shown previously (Blottner et al., 1989a,b; Blottner and Baumgarten, 1992a), this $24 \%$ loss of IML neurons reflects the loss of all spinal cord neurons at this level that project to the adrenal medulla. Animals with NT-4-containing implants $(6 \mu \mathrm{g})$ showed no significant decrease in IML neuron numbers on the lesioned as com- pared with the nonlesioned side (Figs. 6, 7), suggesting that a single dose of NT-4 at $6 \mu \mathrm{g}$ was sufficient to fully protect IML neurons from death induced by target deprivation for at least 4 weeks. A lower dose of NT-4 $(2 \mu \mathrm{g})$ rescued $52 \%$ of preganglionic neurons that would have died (Fig. 7). An identical dose of NT-3 did not offer any protection (Fig. 6,7).

\section{Retrograde transport of NT-4 was not detected}

To clarify whether protection of IML neurons by NT-4 was possibly caused by retrograde transport of NT-4 from the adrenal medulla via preganglionic axons to the IML, autoradiography was performed on spinal cord sections (T7-T10) from eight animals that had received a single injection of iodinated NT-4 into the adrenal medulla. However, neither at 18 nor at 24 hr could any specific signal be detected in the spinal cord. An additional four animals injected with iodinated NT-4 plus a 20 -fold excess of cold NT-4 were also devoid of labeled cell bodies in the spinal cord. However, in all 12 animals injected with radiolabeled NT-4, the adrenal medulla exhibited strong labeling. Moreover, intraadrenal implants of nonradioactive NT-4 $(10 \mu \mathrm{g})$ did not result in an immunocytochemically detectable signal in the IML of the spinal cord after $36 \mathrm{hr}$.

\section{NT-4 induces axon sprouting after adrenomedullectomy}

In the absence of evidence that NT-4 was retrogradely transported from the adrenal medulla to the spinal cord, we hypothesized that NT-4 applied to the medullectomized adrenal gland might not require transport and act locally on axon terminals, e.g., by inducing sprouting of lesioned axons and thereby facilitating their access to alternative trophic factor sources. Staining for AChE activity and synaptophysin immunoreactivity (ir) were used as markers for visualizing axons in animals 4 weeks after surgery. Figure $8 B$ shows that AChE-positive fibers penetrated into NT-4-containing, but not into cytochrome C-containing, gelfoams (Fig. 8A). Moreover, NT-4, but not cytochrome C, induced abundant sprouting of synaptophysin-ir axons in the cortical zona reticularis immediately adjacent to the NT-4containing gelfoam (Fig. 8C,D). Analyses of the time course of appearance of AChE- and synaptophysin-positive nerve fibers in adrenal glands carrying NT-4-containing gelfoam implants revealed no axonal sprouting 4,8 , and $12 \mathrm{~d}$ after surgery (data not shown). These results suggest that axonal sprouting in response to NT-4 is a relatively late event

\section{Mice deficient for TrkB show signs of degeneration of adrenal medullary axons and reduced adherence of synaptic contacts to chromaffin cells}

Having shown that exogenously applied NT-4 stimulated growth of AChE- and synaptophysin-positive axons in the lesioned adrenal medulla, we asked whether mechanisms involving signaling through TrkB might be implicated in axon growth and synapse formation in the early postnatal adrenal medulla. For this analysis we used mice deficient for TrkB rather than NT-4 knock-out mice, because we intended to exclude a putative interference of the TrkB ligand BDNF that is synthesized by IML neurons (data not shown). During ontogeny, the preganglionic nerves to chromaffin cells invade the adrenal medulla at E15 and can be identified in apposition to chromaffin cells starting at E17 (Millar and Unsicker, 1981). A functional innervation indicated by stress- or insulin-mediated discharge of catecholamines commences during the second postnatal week (Kirby and McCarty, 1987). At this time TrkB-deficient mice exhibited pronounced degenerative 

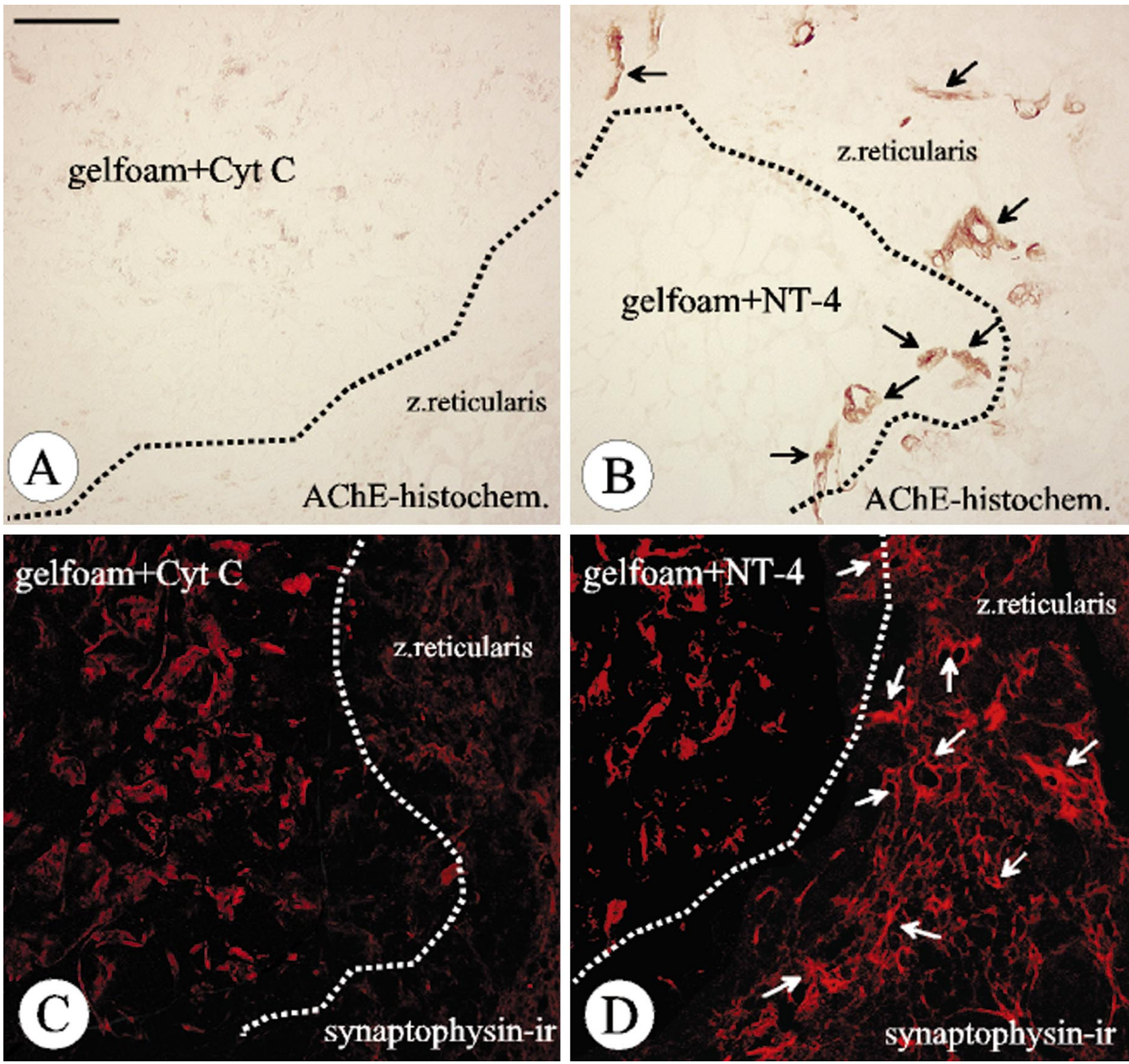

Figure 8. NT-4 implanted in a piece of gelfoam into the medullectomized adrenal gland promotes growth of AChE-positive (B, black arrows) and synaptophysin-ir nerve fibers $(D$, white arrows) in the zona reticularis of the adrenal cortex. AChE-positive and synaptophysin-ir fibers cannot be detected when gelfoams were soaked with cytochrome $\mathrm{C}$ ( gelfoam $+C y t C ; A, C$ ). Note that the red labeling of the gelfoam in $C$ and $D$, in contrast to synaptophysin immunoreactivity in the zona reticularis, is not specific. Scale bar: $A-D, 100 \mu \mathrm{m}$.

changes in axon terminals adjacent to chromaffin cells. Figure 10 shows that $20 \%$ of axon terminals adjacent to chromaffin cells contained signs of degeneration in TrkB knock-out mice as, e.g., whirls of membranes, dense bodies, and swelling (Figs. 9, 10). In contrast, identical ultrastructural changes occurred in only $4 \%$ of adrenal axons in wild-type littermates (Fig. 9). In addition, determinations of the length of apposition of axon membrane to chromaffin target cells indicated that there was a reduction of $25 \%$ in TrkB mutants as opposed to wild-type mice (Fig. 9).

\section{IML neurons are decreased in adult NT-4-deficient mice}

To investigate the putative relevance of adrenomedullary NT-4 for the maintenance of adult IML neurons, numbers of FGlabeled IML neurons in spinal cord segments T7-T10 were de- termined in adult NT-4 $(-/-)$ mice. As shown in Figure 11, numbers of IML neurons in NT-4 (-/-) mice were reduced by $14 \%$ as compared with wild-type littermates. Counts of Nisslstained IML neurons provided identical results (data not shown), suggesting that IML neuron losses in NT-4 (-/-) mice were not caused by altered transport of FG. These data strongly suggest that NT-4 is essential for the maintenance of a subpopulation of IML neurons.

\section{DISCUSSION}

Preganglionic neurons to the adrenal medulla and its chromaffin cells are crucial in regulating synthesis, storage, and secretion of catecholamines and neuropeptides in chromaffin cells, thus contributing essentially to vascular and metabolic body functions 

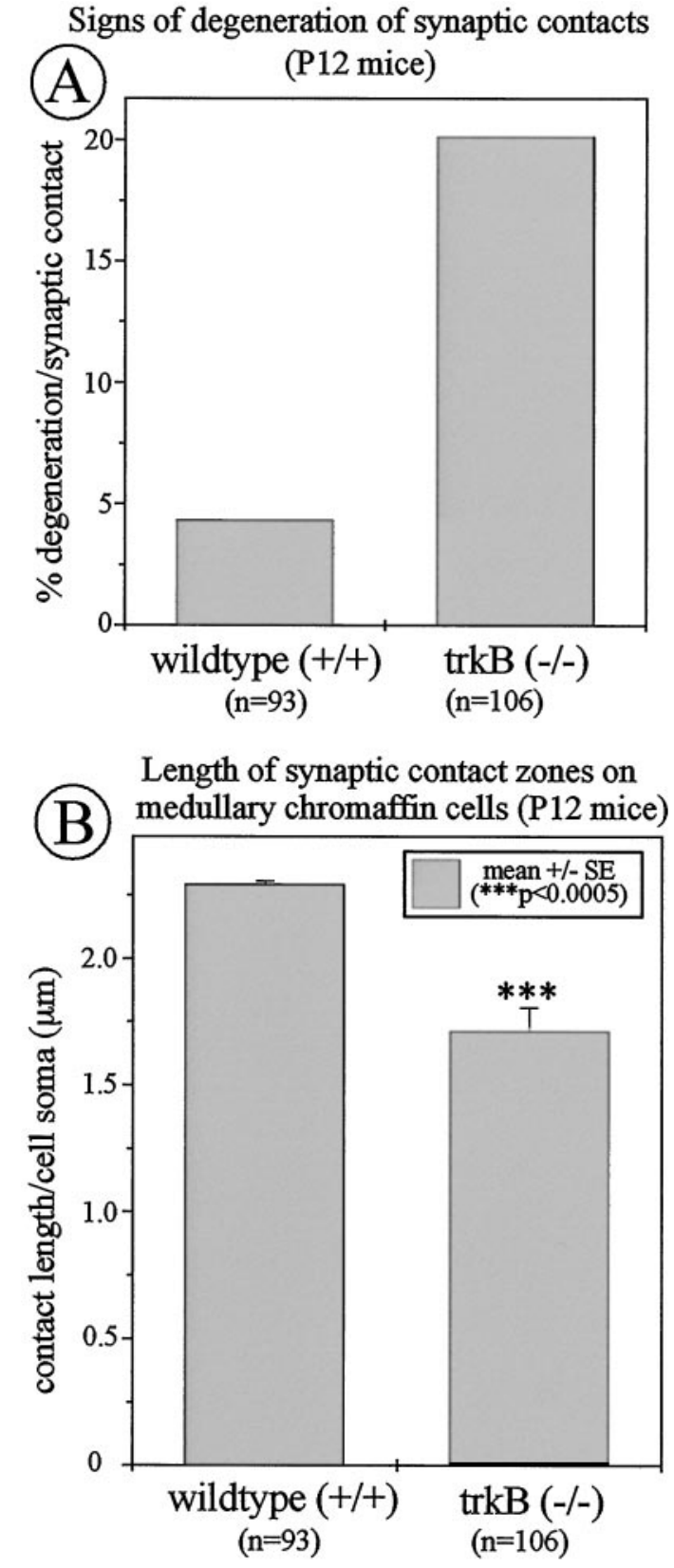

Figure 9. Ultrastructural analysis of axon terminals at chromaffin cells in TrkB $-/-$ mice and wild-type littermates. Knock-outs show a clear increase in the proportion of degenerated nerve terminals $(A)$ and a significant reduction in the length of adhesion zones between axon terminals and adjacent chromaffin cells $(B)$ as compared with wild-type controls.

(Blaschko et al., 1975; Winkler, 1993). The present data indicate that NT-4 and its cognate receptor, TrkB, are important in determining structural integrity of the preganglionic nerves of the adrenal medulla and survival of preganglionic neurons.

\section{Neurotrophins and their receptors in the adrenal medulla}

Evaluation of the present in situ hybridization and immunocytochemical data in conjunction with previous RNase protection and RT-PCR studies suggest that NT-4 is the only neurotrophin detectable in adult rat chromaffin cells with the methods used. Virtually all chromaffin cells are immunoreactive for NT-4. NT-4 is the most divergent member of the neurotrophin family; its expression is ubiquitous and less influenced by environmental signals (for review, see Ibánez, 1996). Furthermore, our in situ hybridizations provide no evidence for BDNF or NT-3 synthesis by chromaffin cells. Rather they suggest that the large sympathetic ganglion cells in the adrenal medulla are a source of BDNF mRNA within the adrenal medulla, consistent with the observation that sympathetic postganglionic neurons synthesize BDNF (Causing et al., 1997). NT-3 mRNA was expressed by cells in the zona reticularis, confirming previous immunocytochemical results by Zhou and Rush (1993).

With regard to adrenal neurotrophin receptors, we (Schober et al., 1997) and others (Michael and Priestley, 1996) have shown that a majority of chromaffin cells in the postnatal rat and mouse adrenal medulla express TrkA. With regard to TrkB and TrkC, our in situ hybridizations revealed weak signals only in the adrenal cortex, but not over medullary chromaffin cells. Taken together, the available data suggest that targets for the chromaffin cell-derived NT-4 may be sought outside the adrenal medulla, either in the cortex or in the innervation of chromaffin cells.

\section{TrkB mRNA is expressed by preganglionic neurons in the spinal cord innervating the adrenal medulla}

It has been reported previously that preganglionic neurons are immunoreactive for full-length TrkB and hypertrophy in response to increased sympathetic neuron-derived BDNF (Causing et al., 1997). In the present study we expanded these data by demonstrating TrkB synthesis in IML neurons and matching TrkB mRNA localization to those preganglionic neurons that can be retrogradely labeled with FG from the adrenal medulla. Consistent with the fact that those spinal cord segments that contain the largest proportion of preganglionic neurons for the innervation of the adrenal medulla also harbor IML neurons projecting to other targets (Schramm et al., 1975; Pyner and Coote, 1994), there were also TrkB mRNA-positive IML neurons lacking a retrograde label.

\section{NT-4 rescues target-deprived IML neurons that innervate the adrenal medulla: possible mechanisms}

If chromaffin cell-derived NT-4 is a growth factor for preganglionic neurons, then we would predict that depriving them of NT-4 would cause structural and/or metabolic changes in IML neuronal cell bodies and their axons. Our data support this notion. Disappearance of the FG-labeled cells rather than a phenotypic change, e.g., enzymatic marker, proves the loss of these IML neurons. Substituting NT-4 at $6 \mu \mathrm{g}$ fully prevented these changes for at least 4 weeks, indicating that NT-4 in fact may be the key target-derived trophic factor for preganglionic neurons, projecting to chromaffin cells. The effect is specific in that NT-3 (this study) and NGF (Blottner et al., 1989b), which are not expressed in the adrenal medulla, cannot protect IML neurons after adrenomedullectomy.

In an attempt to unravel the underlying mechanisms, we examined the question of whether NT-4 was retrogradely transported from the adrenal medulla to the spinal cord. Although negative data are always difficult to interpret, our results suggest that NT-4 may not be transported in this system. Multiple evidence suggests that retrograde transport of a neurotrophic factor is not an absolute prerequisite for transferring information from the site of ligand-receptor interaction in the terminal region of an axon to the neuronal perikaryon. For example, FGF-2, on binding to the receptor, is known to activate a set of G-proteins, which are 

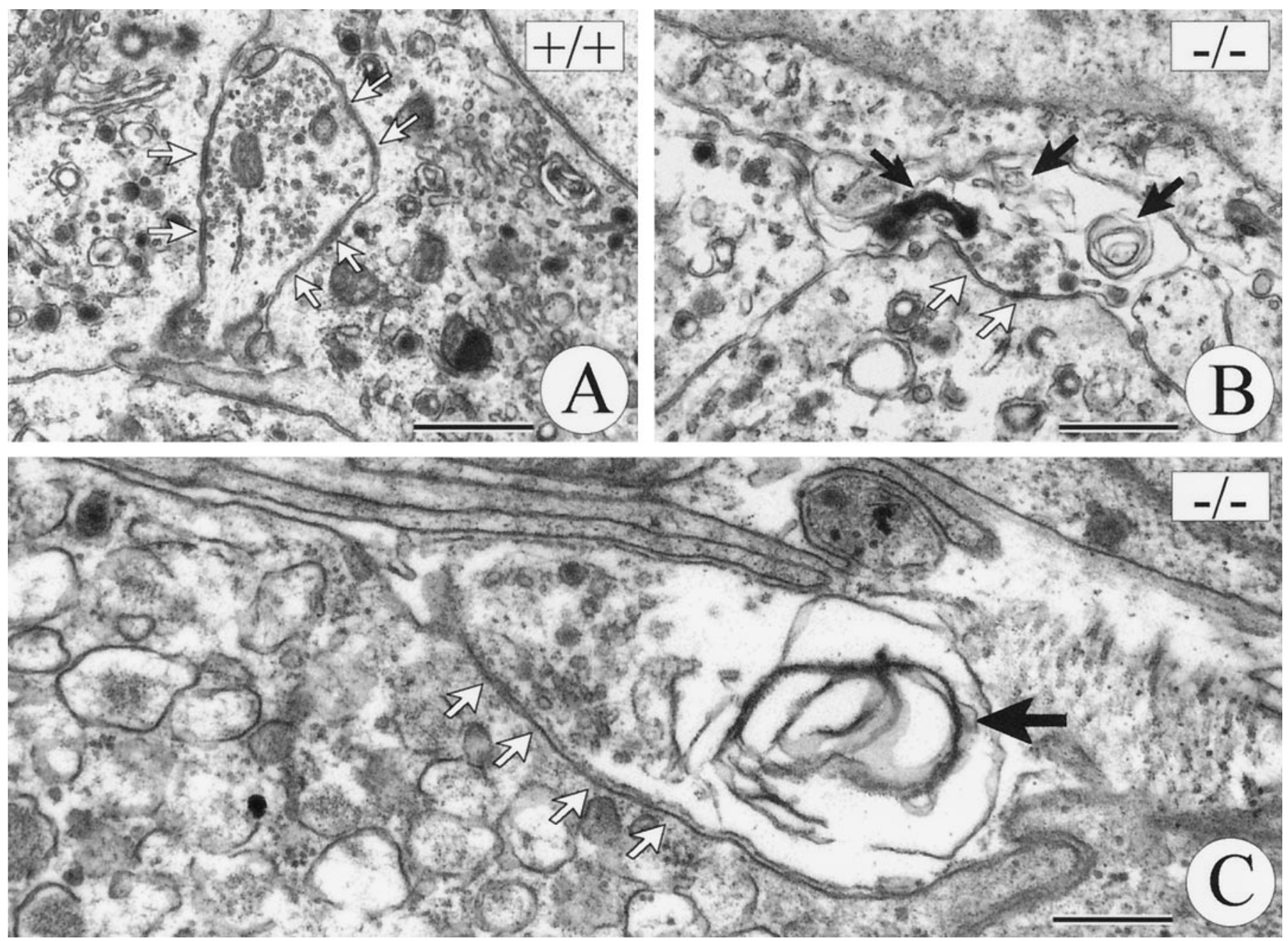

Figure 10. Illustration of ultrastructural signs of degeneration in axon terminals at chromaffin cells of TrkB $-/-(B, C)$ and wild-type $(A)$ mice. Solid arrows mark whorls of membrane and dark inclusion bodies in TrkB mutants $(B, C)$. Open arrows point at sites of adhesion between terminal axons and chromaffin cells. Scale bars: $A, B, 1 \mu \mathrm{m} ; C, 0.5 \mu \mathrm{m}$.

\section{Quantification of IML-neurons in adult mice}

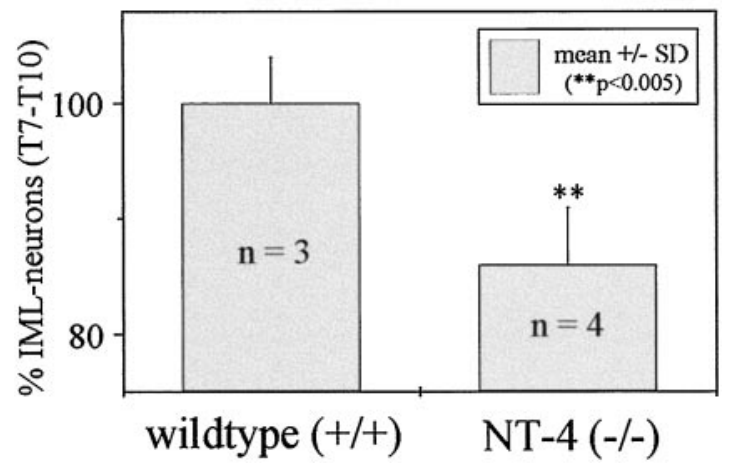

Figure 11. Quantification of IML neurons in NT-4-deficient mice. Numbers of FG-labeled IML neurons are significantly reduced by $14 \%$ as compared with those of wild-type mice.

subsequently transported to the cell body acting as retrograde messengers (Hendry et al., 1995a,b). Our data are consistent with previous studies [Curtis et al. (1995); Ryden et al. (1995); for review, see Ibánez (1996)] that have failed to document retrograde transport of NT-4 in comparable systems.
Several growth factors have been shown to stimulate axonal sprouting, thereby enlarging the terminal field of the axons and facilitating access to neurotrophic factors (Gurney et al., 1992). Both the prominent ingrowth of AChE-positive axons into NT4-containing gelfoams and the dense meshwork of synaptophysin-ir axons in the vicinity of the NT-4-soaked gelfoam indicate that the application of NT-4 significantly stimulated axon sprouting. This result is reminiscent of the observation that intramuscular administration of NT-4 induced sprouting of intact adult motor nerves (Funakoshi et al., 1995). Accordingly, the rescuing effect of NT-4 for target-deprived IML neurons may be the result of an increase in arborization and surface area of terminal axons, which may improve their access to other trophic factors. Such neurotrophic factors might be delivered by cortical or vascular cells. FGF-2 and TGF- $\beta$ are factors synthesized in cortical cells (Thompson et al., 1989; Chambaz et al., 1996), inducible by lesioning (Logan and Berry, 1993), and able to rescue target-deprived preganglionic neurons (Blottner et al., 1989a,b; Blottner and Unsicker, 1990; Blottner et al., 1990). Axonal sprouting in response to NT-4 was not observed during the initial $12 \mathrm{~d}$ after surgery. Because IML neurons do not display visible signs of degeneration until 2 weeks after adrenomedullectomy (Blottner and Baumgarten, 1992b), an axonal sprouting 
response starting at this time would coincide temporally with the period when target-deprived IML neurons start to require protective neurotrophic factors.

\section{Significance of TrkB, NT-4, and other neurotrophic factors for normal development and maintenance of chromaffin cell innervation}

Our present and previous observations (Schober et al., 1997) are consistent with a role of TrkB in regulating perinatal events in chromaffin cell innervation without affecting the survival of the preganglionic nerve cell body during this time. Our results obtained from NT-4-deficient mice, which survive into adulthood, support the notion that NT-4 is of physiological importance in maintaining preganglionic IML neurons. This is the first demonstration of a numerical loss in this neuron population attributable to neurotrophin or other trophic factor deficiencies in loss-offunction mouse mutants. Moreover, it is the first documentation of the physiological relevance of a chromaffin cell-derived trophic factor. Our data also suggest that NT-4 may be important in regulating ontogenetic neuron death of IML neurons, which becomes significant after the first 2 postnatal weeks (Parker et al., 1988). TrkB mutant mice do not survive into the third postnatal week, i.e., we have not been able to compare IML neurons in NT-4 and TrkB mutants.

From the present and previous studies a more detailed picture of the trophic interactions of preganglionic neurons and chromaffin cells emerges. NT-4, FGF-2, and TGF- $\beta$ are all expressed in adrenal medullary cells in distinct temporal patterns (Timmusk et al., 1993; Bieger et al., 1995; Blottner et al., 1996; this study). NT-4 (Timmusk et al., 1993) may be important for perinatal intraadrenal sprouting of preganglionic axons, their early stabilization, regulation of ontogenetic neuron death of IML neurons, and their maintenance during adulthood. TGF- $\beta$ is detectable from E15.5 throughout adulthood (Flanders et al., 1991; Blottner et al., 1996), suggesting putative roles both in establishing and maintaining preganglionic-target cell connections. FGF-2 appears after birth (Grothe and Unsicker, 1990), consistent with its proposed role as a maintenance factor for adult preganglionic neurons. During destruction of the adrenal medulla, each individual factor administered in saturating doses is able to fully prevent degeneration of preganglionic cell bodies. In the physiological unlesioned state, however, each factor may be expressed and delivered at nonsaturating levels, i.e., cooperativity of several factors may fulfill the trophic requirement of preganglionic neurons. This is reminiscent of the motoneuron system, where apparently even more factors converge on a target neuron, although single factors likewise may be sufficient to rescue axotomized motoneurons (Elliott and Snider, 1996).

In conclusion, the present study outlines a role for NT-4 and TrkB in the interactions of chromaffin cells with their preganglionic neurons. Whether these interactions are distinct from or similar to the interactions of sympathetic neurons with their corresponding preganglionic neurons remains to be shown. In contrast to chromaffin cells (Bode et al., 1986; Schober et al., 1997), the number of paravertebral sympathetic neurons and their differentiated properties are regulated by NGF (Snider, 1994). Changes in the number of paravertebral sympathetic neurons are retrogradely propagated, affecting numbers of preganglionic neurons (Oppenheim et al., 1982; Schober et al., 1997). The physiological retrograde trophic factor from paravertebral sympathetic neurons to preganglionic spinal cord neurons has not been identified. Whether BDNF is the correct candidate (Causing et al.,
1997) remains to be clarified once conditional BDNF knock-out animals that survive into adulthood become available. Our analysis of the NT-4 mutants showing a $14 \%$ loss of preganglionic neurons in spinal cord segments T7-T10 clearly suggests that there must be factors in addition to NT-4 that are physiologically relevant for the maintenance of IML neurons.

\section{REFERENCES}

Anderson CR (1992) NADPH diaphorase-positive neurons in the rat spinal cord include a subpopulation of autonomic preganglionic neurons. Neurosci Lett 139:280-284.

Anderson CR, Edwards SL (1994) Intraperitoneal injections of FluoroGold reliably labels all sympathetic preganglionic neurons in the rat. J Neurosci Methods 53:137-141.

Andrä J, Lojda Z (1986) A histochemical method for the demonstration of acetylcholinesterase activity using semipermeable membranes. Histochemistry 84:575-579.

Bieger SC, Henkel A, Unsicker K (1995) Localization of basic fibroblast growth factor in bovine adrenal chromaffin cells. J Neurochem 64:1521-1527.

Blaschko H, Sayers G, Smith DA (1975) Handbook of Physiology, Sect 7: Endocrinology, Vol VI: Adrenal Gland. Washington, DC: American Physiological Society.

Blottner D, Baumgarten HG (1992a) Nitric oxide synthase (NOS)containing sympathoadrenal cholinergic neurons of the rat IML-cell column: evidence from histochemistry, immunohistochemistry, and retrograde labeling. J Comp Neurol 316:45-55.

Blottner D, Baumgarten HG (1992b) Basic fibroblast growth factor prevents neuronal death and atrophy of retrogradely labeled preganglionic neurons in vivo. Exp Neurol 118:35-46.

Blottner D, Unsicker K (1990) Maintenance of intermediolateral spinal cord neurons by fibroblast growth factor administered to the medullectomized rat adrenal gland: dependence on intact organ innervation and cellular organization of implants. Eur J Neurosci 2:378-382.

Blottner D, Brüggemann W, Unsicker K (1989a) Ciliary neurotrophic factor supports target-deprived preganglionic sympathetic spinal cord neurons. Neurosci Lett 105:316-320.

Blottner D, Westermann R, Grothe C, Böhlen K, Unsicker K (1989b) Basic fibroblast growth factor in the adrenal gland. Eur J Neurosci 1:471-478.

Blottner D, Wolf N, Lachmund A, Flanders KC, Unsicker K (1996) TGF- $\beta$ rescues target deprived preganglionic sympathetic neurons in the spinal cord. Eur J Neurosci 8:202-210.

Bode K, Hofmann HD, Müller TH, Otten U, Schmidt R, Unsicker K (1986) Effects of pre- and postnatal administration of antibodies to nerve growth factor on the morphological and biochemical development of the rat adrenal medulla: a reinvestigation. Dev Brain Res 27:139-150.

Causing CG, Gloster A, Aloyz R, Bamji SX, Chang E, Fawcett J, Kuchel G, Miller FD (1997) Synaptic innervation density is regulated by neuron-derived BDNF. Neuron 18:257-267.

Chambaz EM, Souchelnitskiy S, Pellerin S, Defaye G, Cochet C, Feige J-J (1996) Transforming growth factor- $\beta$ s: a multif unctional cytokine family. Horm Res 45:222-226.

Cole JT, Blendy JA, Monaghan, AP, Krieglstein K, Schmid W, Aguzzi A, Fantuzzi G, Hummler E, Unsicker K, Schütz G (1995) Target disruption of the glucocorticoid receptor gene blocks adrenergic chromaffin cell development and severely retards lung maturation. Genes Dev 9:1608-1621.

Curtis R, Adryan KM, Stark JL, Park JS, Compton DL, Weskamp G, Huber LJ, Chao VM, Jaenisch R, Lee K-F, Lindsey RM, DiStefano PS (1995) Differential role of the low affinity neurotrophin receptor (p75) in retrograde axonal transport of the neurotrophins. Neuron 14:1201-1211.

Elliot JL, Snider WD (1996) Motor neuron growth factors. Neurology 47:S47-S53.

Flanders KC, Lüdecke G, Engels S, Cissel DS, Roberts AB, Unsicker K (1991) Localization and actions of transforming growth factor- $\beta$ s in the embryonic nervous system. Development 113:183-191.

Funakoshi H, Belluardo N, Arenas E, Yamamoto Y, Casabona A, Persson H, Ibánez CF (1995) Muscle-derived neurotrophin-4 as an activity-dependent trophic signal for adult motor neurons. Science 268:1495-1499.

Grothe C, Unsicker K (1990) Immunocytochemical mapping of basic 
fibroblast growth factor in the developing and adult rat adrenal gland. Histochemistry 94:141-147.

Grothe C, Unsicker K (1992) Basic fibroblast growth factor in the hypoglossal system: specific retrograde transport, trophic, and lesion-related response. J Neurosci Res 32:317-328.

Gurney ME, Yamamoto H, Kwon Y (1992) Induction of motor neuron sprouting in vivo by ciliary neurotrophic factor and basic fibroblast growth factor. J Neurosci 12:3241-3247.

Hendry IA, Johanson SO, Heydon K (1995a) Retrograde axonal transport of the alpha subunit of the GTP-binding protein Gz to the nucleus of sensory neurons. Brain Res 700:157-163.

Hendry IA, Johanson SO, Heydon K (1995b) Developmental signalling. Clin Exp Pharmacol Physiol 22:563-568.

Ibánez CF (1996) Neurotrophin-4: the odd one out in the neurotrophin family. Neurochem Res 21:787-793.

Kahane N, Kalcheim C (1994) Expression of TrkC receptor mRNA during development of the avian nervous system. J Neurobiol 25:571-584.

Karnovsky MJ, Roots L (1964) A "direct coloring" thiocholine method for cholinesterase. J Histochem Cytochem 12:219-221.

Kirby RF, McCarty R (1987) Oncogeny of functional sympathetic innervation to the heart and adrenal medulla in the preweanling rat. J Auton Nerv Syst 19:67-75.

Konigsmark BW (1970) Methods for counting neurons. In: Contemporary research methods in neuroanatomy (Nauta WJH, Ebesson SOE, eds), pp 315-340. New York: Springer.

Liu X, Ernfors P, Wu H, Jaenisch R (1995) Sensory but not motor neuron deficits in mice lacking NT-4 and BDNF. Nature 375:238-241.

Logan A, Berry M (1993) Transforming growth factor- $\beta 1$ and basic fibroblast growth factor in the injured CNS. Trends Pharmacol 14:337-343.

Michael GJ, Priestley JV (1996) Expression of TrkA and p75 nerve growth factor receptor in the adrenal gland. NeuroReport 7:1617-1622.

Millar TJ, Unsicker K (1981) Catecholamine storing cells in the adrenal medulla of the pre- and postnatal rat. Cell Tissue Res 217:155-170.

Oppenheim RW, Maderdrut JL, Wells DJ (1982) Cell death of motoneurons in the chick embryo spinal cord. VI. Reduction of naturally occurring cell death in the thoracolumbar column of Terni by nerve growth factor. J Comp Neurol 210:174-189.
Parker TR, Kesse WK, Tomlinson A, Coupland RE (1988) Ontogenesis of preganglionic sympathetic innervation of rat adrenal chromaffin cells In: Progress in catecholamine research, Part A: Basic aspects and peripheral mechanism (Dahlström A, Belmaker RH, Sandler M, eds), pp 227-232, New York: Liss.

Pyner S, Coote JH (1994) Evidence that sympathetic preganglionic neurones are arranged in target-specific columns in the thoracic spinal cord of the rat. J Comp Neurol 342:15-22.

Ryden M, Murray-Rust J, Glass D, Ilag LL, Trupp M, Yancopoulos GD, McDonald NQ, Ibánez CF (1995) Functional analysis of mutant neurotrophins deficient in low affinity binding reveals a role for p75 LNGFR in NT-4 signalling. EMBO J 14:1979-1990.

Schober A, Minichiello L, Keller M, Huber K, Layer PG, Roig-López JL, García-Arrarás JE, Klein R, Unsicker K (1997) Reduced acetylcholinesterase (AChE) activity in adrenal medulla and loss of sympathetic preganglionic neurons in TrkA-deficient, but not TrkB-deficient, mice. J Neurosci 17:891-903.

Schramm CP, Adair JR, Stribling JM, Gray LP (1975) Preganglionic innervation of the adrenal gland of the rat. Exp Neurol 49:540-553.

Snider WD (1994) Functions of the neurotrophins during nervous system development: what the knockouts teaching us. Cell 77:627-638.

Suter-Crazzolara C, Lachmund A, Arab SF, Unsicker K (1996) Expression of neurotrophins and their receptors in the developing and adult rat adrenal gland. Mol Brain Res 43:351-355.

Thompson NL, Flanders KC, Smith JM, Ellingsworth LR, Roberts AB, Sporn MB (1989) Expression of transforming growth factor $\beta 1$ in specific cells and tissues of adult and neonatal mice. J Cell Biol 108:661-669.

Timmusk T, Belluardo N, Metsis M, Persson H (1993) Widespread and developmentally regulated expression of neurotrophin-4 mRNA in rat brain and peripheral tissue. Eur J Neurosci 5:605-613.

Unsicker K (1993) The chromaffin cell: paradigm in cell, developmental and growth factor biology. J Anat 183:207-221.

Winkler H (1993) The adrenal chromaffin granule: a model for large dense core vesicles of endocrine and nervous tissue. J Anat 183:237-252.

Zhou XF, Rush RA (1993) Localization of neurotrophin-3-like immunoreactivity in peripheral tissues of the rat. Brain Res 621:189-199. 